\title{
Post-Coronavirus Disease-2019 Syndrome in Healthcare Workers
}

\author{
COVID-19 Enfeksiyonu Geçiren Sağlık Çalışanlarında Post-COVID-19 Sendromunun \\ Incelenmesi
}

\author{
๑ (1) Merve KAPLAN, ๑ Ayşegül AKKOL ÇAMURCU, ๑ Serpil EROL \\ University of Health Sciences Turkey, Haydarpaşa Training and Research Hospital, Clinic of Infectious Diseases and Clinical Microbiology, \\ istanbul, Turkey
}

\section{Abstract}

Introduction: Some patients with Coronavirus disease-2019 (COVID-19) disease have persistent symptoms, and information about the long-term consequences of those who have recovered is limited. Thus, this study aimed to investigate the persistent symptoms of healthcare workers after COVID-19 and the relationship between demographic and clinical characteristics of patients.

Materials and Methods: Healthcare workers who had symptomatic COVID-19 that is proven by reverse transcription-polymerase chain reaction and were diagnosed at least 12 weeks ago were included in the study. Demographic characteristics, comorbidities, and symptoms at the time of diagnosis and that persisted $>3$ weeks were examined in detail using a questionnaire. The effects of COVID-19 on the participants' quality of life were investigated using the Euro0oL five-dimension five-level (EQ-5D-5L) questionnaire and Euro0oL visual analog scale (EQ-VAS).

Results: Of the 121 participants, the mean age was 33.5 years [22-59, standard deviation $(S D)=8.23]$, and the mean time since their diagnoses with COVID-19 was 30.3 weeks (12.7-56.9, SD=12.6). Of the participants, $92 \%(n=112)$ were followed up as outpatients, $63 \%(n=77)$ had symptoms that lasting $>3$ weeks, and the most common symptoms were fatigue $(n=40,33 \%)$, loss of smell $(n=27,22.3 \%)$, and attention-deficit/concentration disorder $(n=25,20.7 \%)$. Of the 77 patients, $19(24.6 \%)$ stated that their symptoms lasted for $>24$ weeks, with loss of smell as the most common symptom. Additionally, 33\% of participants defined their health status as worse than before according to the E0-5D-5L scale and $15 \%$ had a decrease of seven points or more in their EQ-VAS score.

Conclusion: These results revealed that, even in young patients with mild and moderate COVID-19 infection, post-COVID-19 symptoms are at a rate that will affect their quality of life, thus health services should be planned for the rehabilitation of these patients.

Keywords: Post-acute COVID-19 syndrome, long COVID-19, COVID-19, health-related quality of life

\section{$\ddot{\mathrm{O} z}$}

Giriş: Koronavirüs hastalığı-2019 (COVID-19) hastalarının bir kısmında persiste eden semptomlar görülmektedir ve enfeksiyonu atlatanların uzun dönemdeki sağlık durumlarıyla ilgili bilgiler sınırlıdır. Bu çalışma sağlık çalışanlarının COVID-19 enfeksiyonu sonrasındaki persistan semptomlarının değerlendirmesini ve post-COVID-19 semptomlarının demografik ve klinik özellikleri ile ilişkisinin araştırılmasını amaçlamaktadır.

Gereç ve Yöntem: Tanısı gerçek zamanlı-polimeraz zincir reaksiyonu ile kanıtlanmış, semptomatik COVID-19 enfeksiyonu geçiren sağlık çalışanlarından, tanı almasının üzerinden en az 12 hafta geçmiş olanlar çalışmaya dahil edildi. Katılımcıların demografik özellikleri, ek hastalıkları, COVID-19 tanısı sırasındaki semptomları ve üç haftadan uzun süren semptomları anket formu ile ayrıntılı olarak sorgulandı. Katılımcıların kendileri tarafından doldurulan EuroQoL beş-boyut beş-seviye (EQ-5D-5L) anketi ve EuroQoL görsel analog skalası (EQ-VAS) ile COVID-19 hastalığının, katılımcıların yaşam kalitesi üzerine etkileri araştırıldı.

Bulgular: Çalışmaya dahil edilen 121 hastanın ortalama yaşı 33,5 [22-59, standart deviasyon (SD)=8,23], COVID-19 enfeksiyonu tanıSı almasının üzerinden geçen süre ortalama 30,3 haftaydı (12,7-56,9, SD=12,6 hafta). Katılımcıların \%92'si (n=112) ayaktan takip edilmişti. Katılımcıların \%63'ünün ( $n=77)$ COVID-19 enfeksiyonu sonrasında üç haftadan uzun süren semptomları olmuştu ve halsizlik ( $n=40, \% 33)$, koku kaybı (n=27, \%22,3), dikkat eksikliği/konsantrasyon bozukluğu $(n=25, \% 20,7)$, en sık saptanan semptomlardı. Yetmiş yedi katılımcının 19'u (\%24) ise semptomların 24 haftadan

Cite this article as: Kaplan M, Akkol Çamurcu A, Erol S. Post-Coronavirus Disease-2019 Syndrome in Healthcare Workers. Mediterr J Infect Microb Antimicrob 2022;11:16.

Address for Correspondence/Yazışma Adresi: Merve Kaplan MD, University of Health Sciences Turkey, Haydarpaşa

Training and Research Hospital, Clinic of Infectious Diseases and Clinical Microbiology, İstanbul, Turkey

Phone: +90 21654232 32-1904 E-mail: merveaykan1@gmail.com ORCID ID: orcid.org/0000-0001-5063-0922

Received/Geliş Tarihi: 28.03.2021 Accepted/Kabul Tarihi: 30.12.2021

๑Copyright 2022 by the Infectious Diseases and Clinical Microbiology Specialty Society of Turkey

Mediterranean Journal of Infection, Microbes and Antimicrobials published by Galenos Yayınevi.
Presented in: The study was previously presented at the $9^{\text {th }}$ BUHASDER Congress on November 24-28, 
uzun sürdüğünü belirtti ve en sık görülen semptom koku kaybı idi. EQ-5D-5L anketine göre katılımcıların \%33'ü sağlık durumunu eskisinden daha kötü olarak tanımlarken, \%15'inde EQ-VAS skorunda yedi puan ve üzeri düşüş saptandı.

Sonuç: Tüm bu bulgular hafif ve orta şiddetli COVID-19 enfeksiyonu geçiren genç hastalarda dahi uzun vadeli post-COVID-19 semptomlarının yaşam kalitelerini etkileyecek oranlarda olduğunu ve bu hastaların rehabilitasyonu için sağlık hizmetlerinin planlanması gerektiğini göstermektedir.

Anahtar Kelimeler: Post-akut COVID-19 sendromu, uzamış COVID-19, COVID-19, sağlık ilişkili yaşam kalitesi

\section{Introduction}

Coronavirus disease-2019 (COVID-19), which is caused by Severe acute respiratory syndrome-Coronavirus-2 and resulted in the pandemic, is a disease that can present in different clinical spectrums from asymptomatic infection to critical illness and death $^{[1]}$. According to the World Health Organization (WHO) in June 2021, COVID-19 disease has caused over 181 million recorded cases and over three million deaths worldwide ${ }^{[2]}$. Aside from severe cases that resulted in death, the vast majority of those who are infected recover from the disease. Several studies have reported that some patients with COVID-19 have persistent symptoms. This condition is named "post-COVID-19 syndrome," "long COVID," or "Long Haul syndrome."

The WHO reported that the recovery time is approximately two weeks for mild cases and 3-6 weeks for patients with severe or critical illness ${ }^{[3]}$. However, symptoms were later on revealed to persist for weeks or even months in some patients who were not severely or critically ill. The term "long COVID-19" was first used in the Lombardy region of Italy by Dr. Elisa Perego in line with the information obtained from the follow-up of her patients. Later on, thousands of people who had ongoing symptoms and could not perform their daily activities after COVID-19 were posted on social media with the long COVID-19 hashtag, and awareness has been raised worldwide about the symptoms of long COVID-19[4].

No consensus was achieved on the post-COVID-19 syndrome definition. Greenhalgh et al. ${ }^{[5]}$ defined the symptoms that persist between three weeks and 12 weeks as post-acute COVID-19 and symptoms that last for $>12$ weeks as a postCOVID-19 syndrome, in their study. Various studies investigated the different durations of persistent symptoms ${ }^{[6-9]}$.

The initial symptoms and clinical course of COVID-19 are well known; however, information about the long-term health consequences of those who have recovered is limited ${ }^{[10,11]}$. Understanding the long-term effects of COVID-19, risk factors, and predictors of persistent symptoms is important to eliminate those effects and plan health services due to the new cases that still emerge worldwide.

Many possible mechanisms contribute to the pathophysiology of prolonged symptoms. Sequelae due to organ damage, different required duration for each organ system recovery, chronic inflammation or immune response/autoantibody production, rare persistence of the virus in the body, hospitalization and critical illness effects, post-intensive care syndrome, complications due to coronavirus infection, comorbidities and drugs, and psychological and social issues, such as post-traumatic stress disorder, are among the reasons in the development of prolonged symptoms ${ }^{[12]}$.

This study aimed to investigate persistent symptoms of healthcare workers after COVID-19 disease using a questionnaire and the relationship between the persistent symptoms with demographic and clinical characteristics of patients.

\section{Materials and Methods}

A questionnaire was conducted to determine post-COVID-19 symptoms of healthcare workers of our hospital, who were diagnosed with COVID-19. Healthcare workers who had symptomatic diseases that are proven using reverse transcription-polymerase chain reaction (RT-PCR) and were diagnosed at least 12 weeks ago were included in the study to evaluate the long-term effects of COVID-19. Informed written consent was obtained from all patients. The data was collected between April and June 2021.

Demographic characteristics [age, sex, body mass index (BMI), and occupation], comorbidities, symptoms at the time of diagnosis, and symptoms that persisted for $>3$ weeks were examined in detail using the questionnaire. Post-COVID-19 symptoms and their relationship with the demographic characteristics were analyzed.

Additionally, the effects of COVID-19 on the participants' quality of life were investigated using the EuroOoL fivedimension (mobility, self-care, usual activities, pain/ discomfort, and anxiety/depression) five-level (no, slight, moderate, severe, and unable to/extreme problems) (EQ-5D$5 \mathrm{~L}$ ) questionnaire and the EuroOoL visual analog scale (EQVAS) that is filled by the participants. An EQ-5D health state is deemed to be "better" than another if it is better on at least one dimension and is no worse in any other dimension. An EQ-5D health state is deemed to be "worse" than another if it is worse in at least one dimension and is no better in any other dimension. The EQ-VAS provides a quantitative measurement of the patient's perception of their overall health ${ }^{[13]}$. 
Ethical approval was obtained from the Haydarpaşa Training and Research Hospital Clinical Researches Ethical Committee (HNEAH-KAEK 2021/KK/103, date: 15.02.2021).

\section{Statistical Analysis}

Our data were analyzed using the International Business Machines Statistical Package for the Social Sciences Statistics (SPSS) 23 (IBM SPSS, Turkey). Descriptive statistics were stated as frequency, mean, standard deviation (SD), minimum, and maximum values. Categorical variables were analyzed using the chi-square test. Risk factors of symptoms that last for $>3$ weeks were determined with logistic regression analyses. Statistical significance was determined as $p$ values below $5 \%$.

\section{Results}

During the study, 341 healthcare workers were diagnosed with COVID-19 by RT-PCR at least 12 weeks ago. We aimed to reach all; however, only 121 voluntarily answered our questionnaire. Of whom, 39 (32.2\%) were males and 82 $(62.8 \%)$ were females. The mean age was 33.5 years (22-59, $\mathrm{SD}=8.23)$, wherein $82(67.8 \%)$ participants were between the ages of 18-34, 31 (25.6\%) between 35-49, and 8 (6.6\%) over the age of 50 years. The evaluation of chronic diseases of participants revealed that $80(66.1 \%)$ had no disease, whereas 41 (33.9\%) had known chronic diseases. Of the participants, nine (7.4\%) were hospitalized and 112 (92.6\%) were followed up as outpatients. Demographic characteristics and additional conditions are presented in Table 1.

The evaluation of the symptoms of patients during diagnosis revealed that the most common symptoms were fatigue $(n=95,78.5 \%)$, joint pain $(n=77,63.6 \%)$, headache $(n=72$, $59.5 \%)$, loss of smell $(n=60,49.6 \%)$, loss of taste $(n=57$, $47.1 \%)$, sore throat $(n=53,43.8 \%)$, cough $(n=52,43 \%)$, and fever $(n=44,36.4 \%)$. The prevalence of symptoms during acute COVID-19 is presented in Table 2.

The mean time since the participants were diagnosed with COVID-19 was 30.3 weeks (12.7-56.9, SD=12.6 weeks). Participants were asked for symptoms that lasted for $>3$ weeks. Symptoms lasted for $>3$ weeks after COVID-19 infection in $77(63.6 \%)$ participants. Fatigue $(n=40,33 \%)$, loss of smell $(n=27,22.3 \%)$, attention deficit/concentration disorder $(n=25,20.7 \%)$, dyspnea $(n=24,19.8 \%)$, myalgia $(n=24,19.8 \%)$, loss of taste $(n=23,19 \%)$, cough $(n=19$, $15.7 \%)$, joint pain $(n=18,14.9 \%)$, sleep disturbance $(n=14$, $11.6 \%)$, and memory difficulties $(n=13,10.7 \%)$ were the most common symptoms (Graphic 1).

As the participants with dyspnea for $>3$ weeks $(n=24)$ rated their dyspnea, one (4.2\%) had dyspnea at rest, two (8.3\%) had dyspnea while dressing, and 20 (83.3\%) had dyspnea while climbing the stairs.
As the participants $(n=40)$ who complained of fatigue for $>3$ weeks rated their fatigue complaints, 29 (72.5\%) said they could carry out their daily work, five $(12.5 \%)$ spent $<50 \%$ of the day in bed, and three (7.5\%) spent $>50 \%$ in bed. No participant stated total bed confinement (WHO performance scores) ${ }^{[14]}$.

Participants were asked for the duration of their persistent symptoms, and $38(31.4 \%)$ of the 121 participants had symptoms the lasted for $>12$ weeks, which included loss of smell $(n=16,13.2 \%)$, loss of taste $(n=11,9.1 \%)$, fatigue $(n=10$, $8.6 \%)$, attention deficit and concentration disorder $(n=9,7.4 \%)$, dyspnea $(n=8,6.6 \%)$, sleep disturbance $(n=7,5.7 \%)$, cough $(n=5,4.1 \%)$, chest pain $(n=4,3.3 \%)$, memory difficulties $(n=4$, $3.3 \%)$, headache $(n=3,2.4 \%)$, myalgia $(n=3,2.4 \%)$, joint pain $(n=1,0.8 \%)$, sputum $(n=1,0.8 \%)$, constipation $(n=1,0.8 \%)$, and back pain $(n=1,0.8 \%)$.

During the survey, 77 of the 121 participants were diagnosed with COVID-19 before $>24$ weeks. Persistent symptoms lasted for $>24$ weeks in $19(24.6 \%, 19 / 77)$ participants. The most common symptoms lasted for $>24$ weeks including loss of smell $(n=9,11.6 \%)$, loss of taste $(n=5,6.4 \%)$, dyspnea $(n=5,6.4 \%)$, headache $(n=3,3.8 \%)$, fatigue $(n=2,2.5 \%)$, cough $(n=2,2.5 \%)$, attention deficit and concentration disorder $(n=2,2.5 \%)$, memory difficulties $(n=1,1.2 \%)$, sleep disorder $(n=1,1.2 \%)$, back pain ( $n=1,1.2 \%)$, respectively (Graphic 2 ).

Symptoms lasted for $>3$ weeks in 57 (69\%) females and 20 $(51.3 \%)$ males but without statistically significant difference between gender $(\mathrm{p}=0.051)$. No statistically significant correlation was found between age distribution, BMI, occupational group, and symptoms that lasted for $>3$ weeks $(p>0.05)$.

Complaints that lasted for $>3$ weeks were experienced by 16 $(55.2 \%)$ smokers and 61 non-smokers (66.3\%). No statistically significant correlation was found between smoking and persistent complaints $(p=0.277)$.

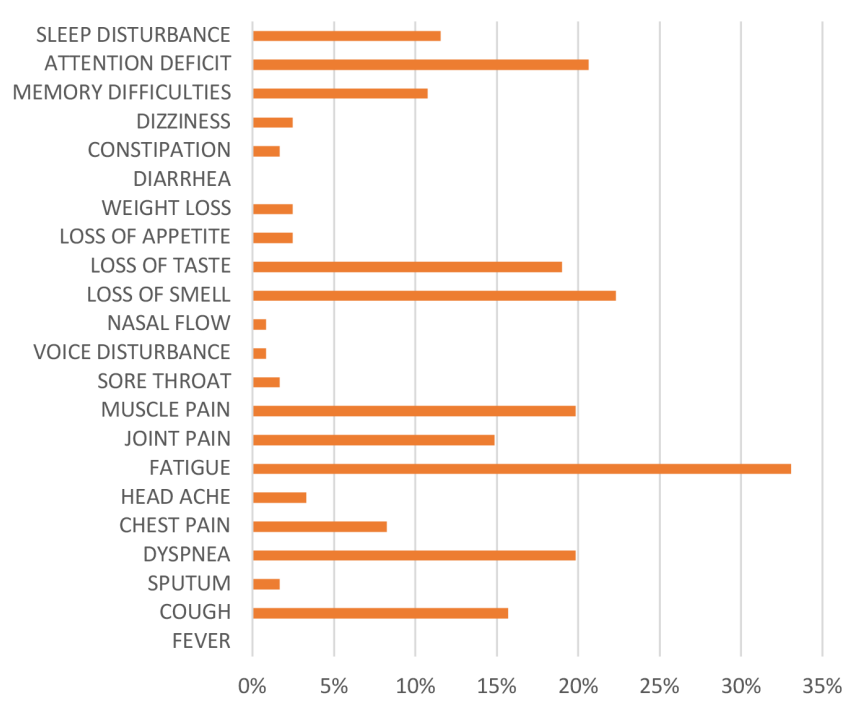

Graphic 1. Distribution of the persistent symptoms 
Table 1. Demographical characteristics and comorbidities of patients

\begin{tabular}{|c|c|c|c|}
\hline & n (\%) & & n (\%) \\
\hline Sex & & Smoking & \\
\hline Male & $39(32.2 \%)$ & Smoker & $29(23.9 \%)$ \\
\hline Female & $82(62.8 \%)$ & Non-smoker & $92(76.1 \%)$ \\
\hline Total & $121(100 \%)$ & Chronic diseases & \\
\hline Age, years & & Yes & $41(33.9 \%)$ \\
\hline Mean age & $33.5(22-59, \mathrm{SD}=8.23)$ & No & $80(66.1 \%)$ \\
\hline $18-34$ & $82(67.8 \%)$ & Asthma & $9(7.4 \%)$ \\
\hline $35-49$ & $31(25.6 \%)$ & Migraine & $7(5.8 \%)$ \\
\hline$>50$ & $8(6.6 \%)$ & Hypertension & $6(5 \%)$ \\
\hline Occupation & & Diabetes mellitus & $3(2.5 \%)$ \\
\hline Doctor & $63(52.1 \%)$ & Heart disease & $3(2.5 \%)$ \\
\hline Nurse & $30(24.8 \%)$ & COPD & $0(0 \%)$ \\
\hline Other healthcare workers & $28(23.1 \%)$ & Chronic renal insufficiency & $0(0 \%)$ \\
\hline BMI & & Cancer & $0(0 \%)$ \\
\hline$<25 \mathrm{~kg} / \mathrm{m}^{2}$ & $72(59.5 \%)$ & COVID-19 follow-up & \\
\hline $25-30 \mathrm{~kg} / \mathrm{m}^{2}$ & $38(31.4 \%)$ & Hospitalized & $9(7.4 \%)$ \\
\hline$>30 \mathrm{~kg} / \mathrm{m}^{2}$ & $11(9.1 \%)$ & Outpatient & $112(92.6 \%)$ \\
\hline
\end{tabular}

BMI: Body mass index, COPD: Chronic obstructive pulmonary disease, SD: Standard deviation, COVID-19: Coronavirus disease-2019

Symptoms lasted for $>3$ weeks in $49(61.3 \%)$ participants without any chronic disease and 28 (68.3\%) with known chronic diseases. No statistical difference was found between those with and without the chronic disease $(p=0.446)$.

The statistical difference in the presence of persistent symptoms between hospitalized and outpatients could not be evaluated due to the low number of hospitalized patients $(n=9)$.

The relationship between the symptoms in the initial period of COVID-19 and post-COVID-19 revealed that the presence of dyspnea [ $\mathrm{p}=0.028, \mathrm{r}=6.514$ (confidence interval $(\mathrm{Cl})$ : 1.2234.729)] and fatigue $[p=0.010, r=4.313(\mathrm{Cl}: 1.411-13.181)]$ at baseline was associated with the occurrence of complaints that lasted for $>3$ weeks. No significant relationship was found between the presence of other complaints and the presence of complaints that lasted for $>3$ weeks.

The EQ-5D-5L quality of life scale data analyses revealed that 40 (33.1\%) participants had worse health status than before (at least one dimension of deterioration and none of them improved)

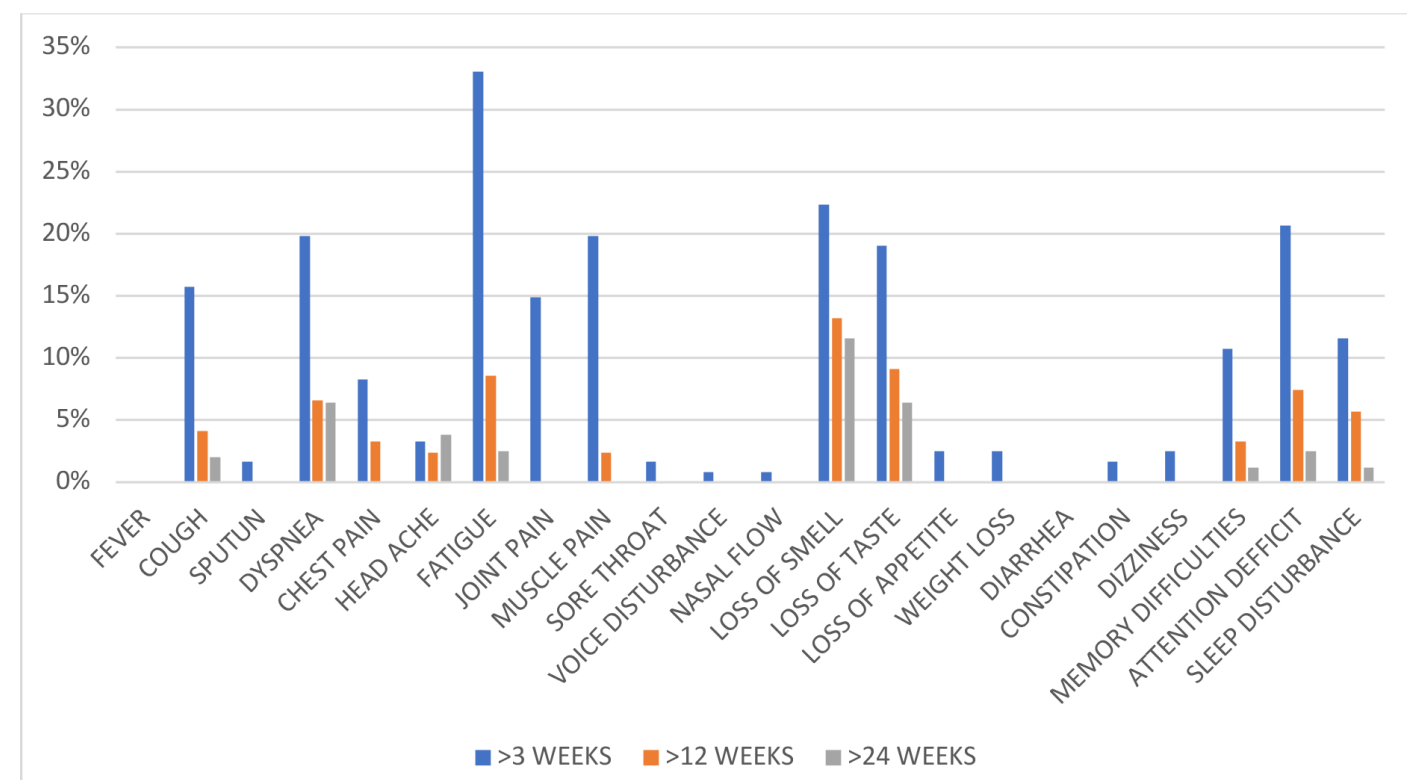

Graphic 2. Distribution of persistent symptoms by duration 
Table 2. Prevalence of symptoms during acute COVID-19 infection

\begin{tabular}{ll}
\hline Symptom & $\mathbf{n}(\%)$ \\
\hline Fever & $44(36.4)$ \\
\hline Cough & $52(43)$ \\
\hline Sputum & $13(10.7)$ \\
\hline Dyspnea & $24(19.8)$ \\
\hline Chest pain & $26(21.5)$ \\
\hline Head ache & $72(59.5)$ \\
\hline Fatigue & $95(78.5)$ \\
\hline Joint pain & $77(63.6)$ \\
\hline Muscle pain & $67(55.4)$ \\
\hline Sore throat & $53(43.8)$ \\
\hline Voice disturbance & $7(5.8)$ \\
\hline Nasal flow & $25(20.7)$ \\
\hline Loss of smell & $60(49.6)$ \\
\hline Loss of taste & $57(47.1)$ \\
\hline Loss of appetite & $34(28.1)$ \\
\hline Diarrhea & $16(13.2)$ \\
\hline Dizziness & $10(8.3)$ \\
\hline CoviD-19: Corravis &
\end{tabular}

COVID-19: Coronavirus disease-2019

and $72(59.1 \%)$ identified their health status as the same before COVID-19 infection. The distribution of EQ-5D-5L dimension responses at baseline and follow-up is presented in Table 3. The Q-VAS score decreased from $83.116(10-100, S D=15.78)$ to $80.438(25-100, S D=15.36)$ after COVID-19. The mean change was $2.68(S D=6.51)$. In studies, the smallest decrease in the Q-VAS score that constitutes clinical significance in respiratory diseases was determined as above seven points ${ }^{[15]}$. A decrease of more than seven points in the Q-VAS score was determined in $19(15.7 \%)$ participants.

\section{Discussion}

Our study revealed that 77 (63.6\%) participants have symptoms that lasted for $>3$ weeks after COVID-19. The study of Tenforde et al. ${ }^{[7]}$ revealed that $65 \%$ of the patients could not return to their normal health in 14-21 days of the disease. Another study revealed that at least one symptom was found in $68 \%$ and $66 \%$ of patients on the $30^{\text {th }}$ and $60^{\text {th }}$ days, respectively ${ }^{[8]}$. In both studies, patients with mild to moderate disease were evaluated similarly to our study. These results reveal that prolonged symptoms are also seen at high rates in patients with mild COVID-19. However, another study revealed that these rates increased to $87 \%$ in patients with a more serious clinical picture ${ }^{[16]}$.

Fatigue (33\%), loss of smell (22.3\%), attention deficit/ concentration disorder $(20.7 \%)$, and dyspnea (19.8\%) were the most common persistent symptoms in our study. Many studies revealed that the most common persistent symptom in mild
Table 3. The distribution of EQ-5D-5L dimension responses at baseline and follow-up

\begin{tabular}{|c|c|c|}
\hline Dimension & $\begin{array}{l}\text { Before COVID-19 } \\
(\%)\end{array}$ & $\begin{array}{l}\text { After COVID-19 } \\
\text { (at the time of } \\
\text { the survey) }(\%)\end{array}$ \\
\hline \multicolumn{3}{|l|}{ Mobility } \\
\hline No problems & $109(90.1)$ & $92(76)$ \\
\hline Slight problems & $9(7.4)$ & $25(20.7)$ \\
\hline Moderate problems & $3(2.5)$ & $4(3.3)$ \\
\hline Severe problems & $0(0.0)$ & $0(0.0)$ \\
\hline Unable to walk & $0(0.0)$ & $0(0.0)$ \\
\hline \multicolumn{3}{|l|}{ Self-care } \\
\hline No problems & $118(97.5)$ & $114(94.2)$ \\
\hline Slight problems & $3(2.5)$ & $7(5.8)$ \\
\hline Moderate problems & $0(0.0)$ & $0(0.0)$ \\
\hline Severe problems & $0(0.0)$ & $0(0.0)$ \\
\hline Unable to wash or dress & $0(0.0)$ & $0(0.0)$ \\
\hline \multicolumn{3}{|l|}{ Usual activities } \\
\hline No problems & 107 (88.4) & $103(85.1)$ \\
\hline Slight problems & $12(9.9)$ & $14(11.6)$ \\
\hline Moderate problems & $2(1.7)$ & $4(3.3)$ \\
\hline Severe problems & $0(0.0)$ & $0(0.0)$ \\
\hline $\begin{array}{l}\text { Unable to do usual } \\
\text { activities }\end{array}$ & $0(0.0)$ & $0(0.0)$ \\
\hline \multicolumn{3}{|l|}{ Pain/discomfort } \\
\hline No pain/discomfort & $102(84.3)$ & 93 (76.9) \\
\hline Slight pain/discomfort & $14(11.6)$ & $22(18.2)$ \\
\hline $\begin{array}{l}\text { Moderate pain/ } \\
\text { discomfort }\end{array}$ & $5(4.1)$ & $6(5.0)$ \\
\hline Severe pain/discomfort & $0(0.0)$ & $0(0.0)$ \\
\hline $\begin{array}{l}\text { Extreme pain/ } \\
\text { discomfort }\end{array}$ & $0(0.0)$ & $0(0.0)$ \\
\hline \multicolumn{3}{|l|}{ Anxiety/depression } \\
\hline Not anxious/depressed & 79 (65.3) & $60(49.6)$ \\
\hline $\begin{array}{l}\text { Slight anxious/ } \\
\text { depressed }\end{array}$ & $22(18.2)$ & $35(28.9)$ \\
\hline $\begin{array}{l}\text { Moderate anxious/ } \\
\text { depressed }\end{array}$ & $13(10.7)$ & $18(14.9)$ \\
\hline $\begin{array}{l}\text { Severe anxious/ } \\
\text { depressed }\end{array}$ & $4(3.3)$ & $3(2.5)$ \\
\hline $\begin{array}{l}\text { Extreme anxious/ } \\
\text { depressed }\end{array}$ & $3(2.5)$ & $5(4.1)$ \\
\hline
\end{tabular}

EQ-5D-5L: EuroQoL five-dimension five-level, COVID-19: Coronavirus disease-2019

and severe disease was fatigue ${ }^{[6,16-19]}$. Our study revealed that complaints, such as attention deficit/concentration disorder (20.7\%), sleep disorder (11.6\%), and memory difficulties (10.7\%), were among the common prolonged symptoms.

Symptoms were observed to last for $>12$ weeks in $31 \%$ and $>24$ weeks in 24\% of the 77 participants who were at least 
24 weeks after the COVID-19 diagnosis. The study of MorenoPérez et al. ${ }^{[9]}$ detected post-COVID-19 symptoms in 50.9\% of the patients on day 77 . This study separately evaluated the frequency of post-COVID-19 symptoms according to disease severity and revealed that $36 \%$ of patients had mild pneumonia and 58\% had severe pneumonia. According to another study, $80.4 \%$ of the hospitalized patients had ongoing symptoms at the $7^{\text {th }}$ month of follow-up ${ }^{[20]}$. Another study revealed that $58 \%$ of patients evaluated on an average of 217 days after discharge had at least one ongoing symptom ${ }^{[21]}$. The study of Huang et al. ${ }^{[22]}$ revealed that $76 \%$ of the patients had ongoing symptoms on the $186^{\text {th }}$ day. Our study contributes to the literature about the frequency of symptoms that lasted for $>6$ months in the long-term outpatient follow-ups.

Fatigue and dyspnea were the most common symptoms that lasted for $>12$ weeks in the hospitalized patient in our study; of which, the most common symptoms include loss of smell $(13 \%)$, loss of taste $(9 \%)$, fatigue $(8 \%)$, and attention deficit and concentration disorder $(7 \%)^{[9,23]}$. The evaluation of the symptoms that lasted for $>24$ weeks was evaluated in our study, the most common symptoms include loss of smell (11\%) and loss of taste (6\%). The study of Vanichkachorn et al. ${ }^{[24]}$ revealed that the most common symptoms at six months were fatigue $(80 \%)$ and shortness of breath (49\%). A study, in which patients were followed for 30-300 days (mean 169 days) were evaluated, revealed loss of smell and taste at a rate of $13.6 \%$, similar to our study. However, fatigue (13.6\%) was reported higher in this study than in our study $(2.5 \%)^{[25]}$.

No significant correlation was found between gender, age, $\mathrm{BMI}$, presence of comorbidity, and presence of post-COVID-19 symptoms since the participants were young patients, did not have severe comorbidities, and the majority (92\%) consisted of mild outpatients. One study, similar to our study, revealed no significant correlation between the clinical characteristics of patients, gender, age, comorbidities, acute infection severity, intensive care unit (ICU) stay, length of stay in the hospital or ICU, and post-COVID-19 symptoms $\mathrm{s}^{[9]}$. Another multicenter study revealed a significant relationship between the female gender, length of hospital stay, number of comorbidities, and number of acute COVID-19 symptoms and post-COVID-19 symptoms ${ }^{[20]}$. These different results obtained from various studies revealed the need for more comprehensive studies with larger series on this subject.

In the evaluation of the relationship between post-COVID-19 symptoms and smoking, 55\% of smokers and $66 \%$ of nonsmokers had complaints that lasted for $>3$ weeks. No statistically significant relationship was found between smoking and persistent complaints. The literature review revealed no other study that examined the relationship between smoking and post-COVID-19 syndrome.
Our study revealed that complaints of dyspnea and fatigue in the initial period of COVID-19 were associated with persistent symptoms. One study revealed that the number of symptoms in the first week of the disease constitutes a risk factor for postCOVID-19 syndrome ${ }^{[26]}$.

Our study revealed that $72 \%$ of patients with fatigue that lasted for $>3$ weeks were able to carry out their daily activities, whereas 83\% described dyspnea that increased when climbing the stairs. Studies that are conducted with severe disease revealed that complaints of fatigue and shortness of breath prevented patients from performing their daily work ${ }^{[6,23]}$. The evaluation of outpatients in our study revealed that these complaints were among the most common persistent symptoms; however, they did not prevent the patients from doing their daily activities.

Health status was defined as worse than before according to the EQ-5D-5L scale in 33\% of our participants and 15\% had a decrease of seven points or more in their EQ-VAS score ${ }^{[14]}$. Some studies revealed that the quality of life of patients with severe COVID-19 was affected by COVID-19 infection, and a decreased Q-VAS score to a clinical significance was observed ${ }^{[6,23]}$. The results of our study showed that the quality of life was significantly affected in patients with mild to moderate COVID-19.

Our study has some limitations. It was conducted in a single center and the sample size was relatively small and most of the patients were outpatients, thus our cohort cannot represent all patients with COVID-19.

\section{Conclusion}

In conclusion, all these findings show that even in young patients with mild and moderate COVID-19 infection, longterm post-COVID-19 symptoms are at a rate that will affect their quality of life, thus health services should be planned for the rehabilitation of these patients.

\section{Ethics}

Ethics Committee Approval: Ethical approval was obtained from the Haydarpaşa Training and Research Hospital Clinical Researches Ethical Committee (HNEAH-KAEK 2021/KK/103, date: 15.02.2021).

Informed Consent: Consent form was filled out by all participants.

Peer-review: Externally peer-reviewed.

\section{Authorship Contributions}

Concept: M.K., A.A.Ç., S.E., Design: M.K., A.A.Ç., S.E., Data Collection or Processing: M.K., A.A.Ç., Analysis or Interpretation: M.K., A.A.Ç., S.E., Literature Search: M.K., A.A.Ç., Writing: M.K., A.A.Ç., S.E. 
Conflict of Interest: No conflict of interest was declared by the authors.

Financial Disclosure: The authors declared that this study received no financial support.

\section{References}

1. Yildiz-Aysert P, Dizbay M. Clinical features and treatment of COVID-19. Gazi Med J. 2020;2:255-9.

2. WHO Coronavirus (COVID-19) Dashboard 2021. Last accessed date: 2021 Jun 28. Available from: https://covid19.who.int/

3. Report of the WHO-China Joint Mission on Coronavirus Disease 2019 (COVID-19) 28 February 2020. Last accessed date: 2021 Jul 22. Available from: https://www.who.int/publications/i/item/report-of-the-who-chinajoint-mission-on-coronavirus-disease-2019-(covid-19)

4. Callard F, Perego E. How and why patients made Long Covid. Soc Sci Med. 2021;268:113426.

5. Greenhalgh T, Knight M, Buxton M, Husain L. Management of post-acute covid-19 in primary care. BMJ 2020;370:m3026.

6. Halpin SJ, Mclvor C, Whyatt G, Adams A, Harvey O, McLean L, Walshaw C, Kemp S, Corrado J, Singh R, Collins T, O'Connor RJ, Sivan M. Postdischarge symptoms and rehabilitation needs in survivors of COVID-19 infection: A cross-sectional evaluation. J Med Virol. 2021;93:1013-22.

7. Tenforde MW, Kim SS, Lindsell CJ, Billig Rose E, Shapiro NI, Files DC, Gibbs KW, Erickson HL, Steingrub JS, Smithline HA, Gong MN, Aboodi MS, Exline MC, Henning DJ, Wilson JG, Khan A, Qadir N, Brown SM, Peltan ID, Rice TW, Hager DN, Ginde AA, Stubblefield WB, Patel MM, Self WH, Feldstein LR; IVY Network Investigators; CDC COVID-19 Response Team; IVY Network Investigators. Symptom duration and risk factors for delayed return to usual health among outpatients with COVID-19 in a multistate health care systems network-United States, March-June 2020. MMWR Morb Mortal Wkly Rep. 2020;69:993-8.

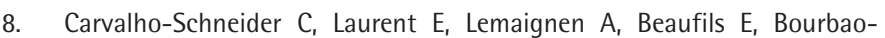
Tournois C, Laribi S, Flament T, Ferreira-Maldent N, Bruyère F, Stefic $K$, Gaudy-Graffin C, Grammatico-Guillon L, Bernard L. Follow-up of adults with noncritical COVID-19 two months after symptom onset. Clin Microbiol Infect 2021;27:258-63.

9. Moreno-Pérez O, Merino E, Leon-Ramirez JM, Andres M, Ramos JM, ArenasJiménez J, Asensio S, Sanchez R, Ruiz-Torregrosa P, Galan I, Scholz A, Amo A, González-delaAleja P, Boix V, Gil J; COVID19-ALC research group. Postacute COVID-19 syndrome. Incidence and risk factors: A Mediterranean cohort study. J Infect. 2021;82:378-83.

10. Şenyiğit A. COVID-19 Pandemisi. Klinik, Tanı, Tedavi ve Korunma. Dicle Tıp Dergisi. 2021;48:176-86.

11. Türktaş H, Oğuzülgen IK. COVID-19 sonrası akciğer sekelleri: uzun dönem takip ve tedavi. Tuberk Toraks. 2020;68:419-29.

12. Nalbandian A, Sehgal K, Gupta A, Madhavan MV, McGroder C, Stevens JS, Cook JR, Nordvig AS, Shalev D, Sehrawat TS, Ahluwalia N, Bikdeli B, Dietz D, Der-Nigoghossian C, Liyanage-Don N, Rosner GF, Bernstein EJ, Mohan S, Beckley AA, Seres DS, Choueiri TK, Uriel N, Ausiello JC, Accili D, Freedberg DE, Baldwin M, Schwartz A, Brodie D, Garcia CK, Elkind MSV, Connors JM, Bilezikian JP, Landry DW, Wan EY. Post-acute COVID-19 syndrome. Nat Med. 2021;27:601-15.

13. EQ-5D User Guides. Last accessed date: 2021 Dec 2. Available from: https:// euroqol.org/publications/user-guides/

14. Oken MM, Creech RH, Tormey DC, Horton J, Davis TE, McFadden ET, Carbone PP. Toxicity and response criteria of the Eastern Cooperative Oncology Group. Am J Clin Oncol.1982;5:649-56.
15. Nolan CM, Longworth L, Lord J, Canavan JL, Jones SE, Kon SS, Man W. The EQ-5D-5L health status questionnaire in COPD: validity, responsiveness and minimum important difference. Thorax. 2016;71:493-500.

16. Carfi A, Bernabei R, Landi F; Gemelli Against COVID-19 Post-Acute Care Study Group. Persistent symptoms in patients after acute COVID-19. JAMA. 2020;324:603-5.

17. Mahmud R, Rahman MM, Rassel MA, Monayem FB, Sayeed SKJB, Islam MS, Islam MM. Post-COVID-19 syndrome among symptomatic COVID-19 patients: A prospective cohort study in a tertiary care center of Bangladesh. PloS One. 2021;16:e0249644.

18. Kamal $M$, Abo Omirah $M$, Hussein $A$, Saeed $H$. Assessment and characterisation of post-COVID-19 manifestations. Int J Clin Pract. 2021;75:e13746.

19. Malik J, Zaidi SMJ, Iqbal R, Khan K, Ali M, Rana AS, Waqar AU, Ishaq U. Post-acute COVID-19 syndrome and its prolonged effects: An updated systematic review. medRxiv. 2021.

20. Fernández-de-Las-Peñas $C$, Palacios-Ceña $D$, Gómez-Mayordomo $V$, Rodríuez-Jiménez J, Palacios-Ceña $M$, Velasco-Arribas $M$, Guijarro $C$, dela-Llave-Rincón Al, Fuensalida-Novo $\mathrm{S}$, Elvira-Martínez CM, Cuadrado ML, Arias-Navalón JA, Florencio LL, Ortega-Santiago R, Molina-Trigueros U, Sebastián-Viana T, Torres-Macho J, Canto-Diez G, Plaza-Canteli S, Cigarán-Méndez $\mathrm{M}$, Ambite-Quesada $\mathrm{S}$, Hernández-Barrera V, Arias-Buría $\mathrm{JL}$, Arendt-Nielsen L. Long-term post-COVID symptoms and associated risk factors in previously hospitalized patients: A multicenter study. J Infect. 2021;83:237-79.

21. Munblit D, Bobkova P, Spiridonova E, Shikhaleva A, Gamirova A, Blyuss 0 , Nekliudov $N$, Bugaeva $P$, Andreeva $M$, DunnGalvin $A$, Comberiati $P$, Apfelbacher C, Genuneit J, Avdeev S, Kapustina V, Guekht A, Fomin V, Svistunov AA, Timashev $P$, Drake TM, Hanson SW, Merson L, Horby $P$, Sigfrid L, Scott JT, Semple MG, Warner JO, Vos T, Olliaro P, Glybochko P, Butnaru D, Sechenov StopCOVID Research Team. Risk factors for longterm consequences of COVID-19 in hospitalised adults in Moscow using the ISARIC Global follow-up protocol: StopCOVID cohort study. MedRxiv. 2021.

22. Huang C, Huang L, Wang Y, Li X, Ren L, Gu X, Kang L, Guo L, Liu M, Zhou X, Luo J, Huang Z, Tu S, Zhao Y, Chen L, Xu D, Li Y, Li C, Peng L, Li Y, Xie W, Cui D, Shang L, Fan G, Xu J, Wang G, Wang Y, Zhong J, Wang C, Wang J, Zhang D, Cao B. 6-month consequences of COVID-19 in patients discharged from hospital: a cohort study. Lancet. 2021;397:220-32.

23. Garrigues $E$, Janvier $P$, Kherabi $Y$, Le Bot $A$, Hamon $A$, Gouze $H$, Doucet L, Berkani S, Oliosi E, Mallart E, Corre F, Zarrouk V, Moyer JD, Galy A, Honsel V, Fantin B, Nguyen Y. Post-discharge persistent symptoms and health-related quality of life after hospitalization for COVID-19. J Infect. 2020;81:4-6.

24. Vanichkachorn G, Newcomb R, Cowl CT, Murad MH, Breeher L, Miller S, Trenary M, Neveau D, Higgins S. Post COVID-19 Syndrome (Long Haul Syndrome): Description of a Multidisciplinary Clinic at the Mayo Clinic and Characteristics of the Initial Patient Cohort. Mayo Clin Proc. 2021;96:1782-91.

25. Logue JK, Franko NM, McCulloch DJ, McDonald D, Magedson A, Wolf CR, Chu HY. Sequelae in adults at 6 months after COVID-19 infection. JAMA Netw Open. 2021;4:e210830.

26. Sudre CH, Murray B, Varsavsky T, Graham MS, Penfold RS, Bowyer RC, Pujol JC, Klaser K, Antonelli M, Canas LS, Molteni E, Modat M, Jorge Cardoso M, May A, Ganesh S, Davies R, Nguyen LH, Drew DA, Astley CM, Joshi AD, Merino J, Tsereteli N, Fall T, Gomez MF, Duncan EL, Menni C, Williams FMK, Franks PW, Chan AT, Wolf J, Ourselin S, Spector T, Steves CJ. Attributes and predictors of long COVID. Nat Med. 2021;27:626-31. 